\title{
Kilka uwag o tympanonie w portalu zamku bierzgłowskiego
}

Monika Dzienis

Toruń

Badania nad portalem zamku bierzgłowskiego mają już przeszło 150-letnią tradycję ${ }^{1}$ i obejmują przynajmniej kilka zagadnień: ikonografię, styl, sens ideowy całości. Ich efekt jest jednak daleki od zadowalającego - do czego w znacznym stopniu przyczynia się stan zachowania zabytku - gdyż nadal niepewna jest nie tylko identyfikacja wyobrażonych postaci, ale nawet to, w jakiej pozie zostały przedstawione. Nie wiemy też, czy litery otaczające łuk portalu tworzą (tworzyły) jakiś logiczny tekst, czy nie. Chciałabym przedstawić poniżej kilka spostrzeżeń, jakie zrodziły się w wyniku niedawnej bezpośredniej konfrontacji z tym zabytkiem, które, być może, wniosą coś nowego do tematu.

1. Skulona postać w prawym polu tympanonu, tak różnie określana $\mathrm{w}$ literaturze ${ }^{2}$, to niewątpliwie przedstawienie śpiącego rycerza ${ }^{3}($ il. 1).

\footnotetext{
${ }^{1}$ Odsyłam do omówień stanu badań u: T. Jurkowlaniec, Gotycka rzeźba architektoniczna w Prusach, Wrocław 1989, s. 24, 37, 59-62, 132; J. Frycz, hasło: Bierzgłowo Zamek, [w:] Architektura gotycka w Polsce, red. T. Mroczko, M. Arszyński, t. 2, Katalog zabytków, Warszawa 1995, s. 27; K. Zawadzka, Portal bramy wjazdowej do zamku krzyżackiego w Bierzgłowie, Rocznik Toruński 37, 2010, s. 7-36; eadem, hasło: Tympanon z Bierzglowa, [w:] Fundacje artystyczne na terenie państwa krzyżackiego w Prusach. Katalog wystawy w Muzeum Zamkowym w Malborku 25 czerwca-12 września 2010 roku, red. B. Pospieszna, t. 1, s. 205.

${ }^{2}$ Zob. J. Heise, Die Bau- und Kunstdenkmäler der Provinz Westpreussen, Bd. 2: Kulmerland und Löbau, H. 7: Der Kreis Thorn, Danzig 1889, s. 112: „eine knieende Gestalt"; M. Kutzner, Propaganda władzy w sztuce Zakonu Niemieckiego w Prusach,
} 
Nie zwrócono dotąd uwagi na jego upozowanie wyraźnie akcentujące stan pogrążenia we śnie: rycerz ma podkurczone nogi i łukowato wygięty korpus (przypominając „zwinięcie się w kłębek”). Wyeksponowano jego prawe ramię, swobodnie leżące na rynsztunku, ale jednocześnie „dla wygody” podłożone pod silnie przechyloną, jak gdyby bezwładnie opadającą głowę ${ }^{4}$. Dłoń nie trzyma miecza, śpiący położył ją otwartą na jego ostrzu (rzeźbiarz, tworząc te „nawarstwienia”, wykonał niełatwe zadanie ukazania aż czterech „planów” w sumarycznej formie, kolejno: tarczy, ułożonego na niej miecza, ramienia i głowy $\mathrm{z}$ korpusem). Przedstawianie śpiącego $\mathrm{w}$ taki właśnie sposób to częsty motyw w sztuce średniowiecznej, występujący szczególnie w scenach Zmartwychwstania (śpiący żołnierze u Grobu) i Modlitwy w Ogrójcu (śpiący apostołowie). Te pierwsze wydają się być najlepszym wzorcem dla wyrażenia snu rycerza $\mathrm{z}$ racji wykonywanej profesji $-\mathrm{z}$ bronią w zanadrzu (często w konfiguracji podobnej do bierzgłowskiej). Podobny schemat - skulenia ciała (czasem ekspresyjnie przerysowany, zob. il. 2) i głowy spoczywającej na wysuniętym ramieniu podczas snu $\mathrm{w}$ warunkach polowych - odnajdziemy w licznych przedstawieniach ${ }^{5}$.

[w:] Sztuka w kręgu Zakonu Krzyżackiego w Prusach i Inflantach. Studia BorussicoBaltica-Torunensia Historiae Artium, 2, red. M. Woźniak, Toruń 1995, s. 17-67, s. 32 „pochylona w geście homagialnym, oddaje jeźdźcy swą tarczę i miecz”; powtórzył to w: idem, Die Herrschaftspropaganda in der Kunst des Deutschen Ordens in Preussen, [w:] Echte Wehrhaftigkeit oder martialische Wirkung. Zur praktischen Funktion und zum Symbolcharakter von Wehrelementen profaner und sakraler Bauten im Deutschordensland Preussen und im Ostseeraum, Köln 2000, s. 253-302, s. 269; K. Zawadzka, Portal, s. 22: „przyciskająca do piersi miecz”. Jako „skulona” trafnie określona m.in. przez: G. Jurkowlaniec, T. Płóciennik, Inskrypcja na bramie zamku krzyżackiego w Bierzgłowie, [w:] Inskrypcje toruńskie, red. I. Sawicka, Toruń 1999, s. 75-86, s. 79; K. Zawadzka, Tympanon z Bierzgłowa, s. 25; eadem, Portal, s. 22; A. Błażejewska, Rzeźba w Prusach krzyżackich do połowy XIV wieku. Źródła stylu, Torun 2012, s. 66: „skulona bądź zgięta w głębokim skłonie”.

${ }^{3}$ Wzmiankowała o tym Bogna Jakubowska w referacie wygłoszonym 29 marca 2012 r. w Instytucie Zabytkoznawstwa i Konserwatorstwa UMK w Toruniu obok innych możliwości „odczytu”, jednak nie rozwijając problemu i nie zajmując wobec niego stanowiska.

${ }^{4}$ Tym samym głowa przesłania nie tylko ramię, ale i fragment miecza.

${ }^{5}$ Na przykład il. 12: Trzy niewiasty u Grobu i Wniebowstąpienie - relief z kości słoniowej (ok. 400 r., Monachium), il. 134: Trzy niewiasty u Grobu - miniatura z tzw. 
Wyobrażenie śpiącego w tympanonie bierzgłowskim znajduje swój ideowy „odpowiednik” w dekoracji kapitelu portalu prowadzącego do zamku konwentualnego w Malborku (jest to istotne, zwłaszcza ze względu na kontekst: portale zamkowe $\mathrm{z}$ tego samego czasu ${ }^{6}$ !), gdzie na ceramicznych kapitelach wyrzeźbiono głowy śpiących rycerzy zakonu krzyżackiego. Kazimierz Pospieszny określił ich sens ideowy jako strażników Castrum Patris, którego załoga może spać spokojnie pod czuwa-

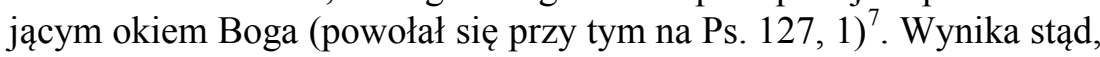
że motyw snu rycerza/strażnika mógł mieć dla Krzyżaków jakiś głębszy sens, jeśli użyto go w obu portalach.

2. Identyfikacja rycerza $\mathrm{w}$ prawym polu jako śpiącego powoduje, że zestawienie go z kroczącą postacią po przeciwnej stronie tympanonu tworzy - jako całość - nowe znaczenie. W tym kontekście zrozumiałe staje się zaakcentowanie ruchu (kroczenia) u postaci po lewej stronie (il. 3) $)^{8}$. Jej ruch to przeciwieństwo snu; obie postacie, dzięki „opozycji”: marsz-sen, obrazują dwojaką czujność rycerzy Zakonu9 (śpiący na rynsztunku).

Sakramentarza z Minden z XI w. (szczególnie postać w prawym dolnym rogu, leżąca na tarczy, z ręką podłożoną pod głowę), il. 145: Zmartwychwstanie - miniatura z Kalendarza (XIII w., Drezno), il. 146: Trzy niewiasty u Grobu - miniatura z Ewangeliarza (początek XIII w., Brandenburg), il. 147: Zmartwychwstanie, Mistrz z Wyższego Brodu (1350 r.), il. 150: Zmartwychwstanie, Mistrz Francke (1425 r., tzw. EnglandfahrerAltar), il. 153: Zmartwychwstanie, Wit Stosz (1477-1489, Ołtarz Mariacki w Krakowie) u: H. Möbius, Passion und Auferstehung in Kultur und Kunst des Mittelalters, Berlin 1978.

${ }^{6}$ Choć stanowiska badaczy różnią się nieco, to mieści się ono w granicach ostatniej ćwierci XIII w., por. m.in. T. Jurkowlaniec, op. cit., s. 60, 132 i 174; ostatnio: K. Pospieszny, Domus Malbork. Zamek krzyżacki w typie regularnym, Torun 2014, s. 89-90: portal z Malborka, s. 267: portal z Bierzgłowa.

${ }^{7}$ K. Pospieszny, op. cit., s. 267 , il. 83 na s. 92.

${ }^{8} \mathrm{~W}$ literaturze określana różnie: T. Jurkowlaniec, op. cit., s. 60: jako „pieszego rycerza z tarczą i mieczem"; niefortunnie u: G. Jurkowlaniec, T. Płóciennik, op. cit., s. 77: „przedstawia ona stojącego rycerza z tarczą”; M. Kutzner, Die Herrschaftspropaganda, s. 269: „stehender”. Jako krocząca m.in. u: K. Zawadzka, Tympanon z Bierzgłowa, s.25; eadem, Portal, s. 21-22; A. Błażejewska, op. cit., s. 66.

${ }^{9}$ K. Rybka w postaciach bierzgłowskich rozpoznał wojowników pruskich na podstawie analizy ich uzbrojenia, dostrzegając pawęż i hełm stożkowy: K. Rybka, Uzbrojenie Prusów w świetle badań nad antropomorficznymi rzé́bami kamiennymi zwanymi babami, [w:] Pruskie baby kamienne. Fenomen kulturowy czy europejska codzien- 
3. Czy tak odczytany sens wyobrażonych rycerzy pozwala na weryfikację identyfikacji zagadkowej centralnej postaci (il. 4) ? ${ }^{10}$ Spośród dotychczasowych propozycji dwie możliwości wydają się najbardziej prawdopodobne: Chrystus-Apokaliptyczny Jeździec ${ }^{11}$ albo Christomimetes - cesarz $^{12}$ (?), św. rycerz (?). Mandorla - poza Chrystusem - przynależy też innym osobom o wyjątkowym statusie: Marii, ewangelistom ${ }^{13}$ czy Pomazańcowi Bożemu (Naśladowcy Chrystusa), chociaż sporadycznie. Te dwie ostatnie możliwości potwierdza miniatura w akwizgrańskim Ewangeliarzu Ottona III (ok. 990 r.) z wizerunkiem cesarza Ottona III w otoku mandorli, namaszczanego przez Boga ${ }^{14}$. Krzyżacy byli poddanymi cesarza, a status równy książętom Rzeszy otrzymali z jego nadania $^{15}$. W komentarzu do Apokalipsy Hesslera funkcjonuje wiele

ność?, red. J. M. Łapo, G. Białuński, Olsztyn 2007, 35-64, s. 40, 43; za nim: K. Zawadzka, Tympanon z Bierzgłowa, s. 25; eadem, Portal, s. 19. Te części uzbrojenia wprawdzie mają obce pochodzenie, ale przez długi czas funkcjonowały u rycerzy krzyżackich, por. A. Nowakowski, Uzbrojenie wojsk krzyżackich w Prusach w XIV w. i na poczatku $X V$ w., Łódź 1980, ryc. 13 na s. 41: nagrobek wielkiego mistrza z pawężą, s. 46: według autora portal bierzgłowski jest zbyt źle zachowany, by rozpoznać uzbrojenie w sposób wiarygodny, s. 66, 102-103, 106.

${ }^{10}$ Pomijam te, które z całą pewnością można wyeliminować: Ucieczka do Egiptu, Wjazd Chrystusa do Jerozolimy, św. Marcin z żebrakiem, Herman von Salza czy scena fundacyjna, por. odsyłacz do stanu badań w przyp. 1. M. Kutzner, Propaganda wła$d z y$, s. 17-67, przedstawienie bierzgłowskie interpretuje jako manifest programu politycznego Zakonu. Trzy postacie w tympanonie miały być jego przedstawicielami, nieutożsamianymi z konkretnymi osobami.

${ }^{11}$ Tezę tę wygłosiła wspomniana już B. Jakubowska, widząc w tympanonie bierzgłowskim ideę Sądu Ostatecznego/Paruzji (badaczka stosowała te pojęcia wymiennie) i wiążąc ją z symboliką środka, muru/granicy. Według Jakubowskiej bezdyskusyjnym argumentem jest mandorla, która przynależy jedynie Chrystusowi i Marii. Zwróciła uwagę na przecinający szyję Jeźdźca miecz, który skojarzyła z wyobrażeniami Chrystusa Apokaliptycznego.

${ }^{12}$ T. Jurkowlaniec, op. cit., s. 37, bierze pod uwagę ,"cesarza Konstantyna (?) z personifikacją pokonanego pogaństwa pod kopytami konia”.

${ }^{13} \mathrm{Na}$ przykład wyobrażenie św. Łukasza w mandorli w tzw. Ewangeliarzu Ottona III (Monachium) z ok. X/XI w., por. P. Skubiszewski, Malarstwo karolińskie i przedromańskie, Warszawa 1973, s. 188, il. 65, s. 190, przy tym autor wspomina o „zerwaniu z tradycyjnym przedstawieniem ewangelistów".

${ }^{14}$ Ibid., s. 186, il. 62, s. 195: cesarz jako imago Christi.

${ }^{15}$ Zob. M. Kutzner, Propaganda władzy, s. 21. 
miniatur, na których rycerze krzyżaccy „ramię $\mathrm{w}$ ramię” $\mathrm{z}$ cesarzem walczą z poganami (wojskiem szatana) ${ }^{16}$. Jednak wyobrażenie cesarza w tympanonie bierzgłowskim wydaje się mniej prawdopodobne niż Chrystusa. Za wizerunkiem Chrystusa przemawiają przede wszystkim symboliczne postacie rycerzy (gotowych do walki), kompensujące całą wykładnię swojego posłannictwa. Ta kompletna, prosta wykładnia, składająca się z postaci-znaków, odnosi się do relacji rycerzy (Chrystusowych) wobec osoby otoczonej chwałą. Należy zwrócić uwagę na sposób ukazania miecza względem postaci ${ }^{17}$, której głowa jest umieszczona na jego tle. Ta zachowana część płaskorzeźby rzeczywiście może budzić skojarzenie z Chrystusem Apokaliptycznym, gdy weźmiemy pod uwagę wyobrażenia Chrystusa-Jeźdźca, z mieczem wydobywającym się z Jego ust lub przedstawionym na ich tle lub na tle Jego głowy (Ap. 19, 1121); rzadko głowa pojawia się na tle miecza ${ }^{18}$ (u Chrystusa już nie jako Jeźdźca). Miniatura z „The Queen Mary Apocalypse” (1. ćwierć XIV w.) ukazuje Chrystusa we wspomniany wyżej sposób, ale $z$ uniesioną prawą ręką, w której trzyma księgę, i prowadzi na wojnę krzyżowców (il. 5). Uniesione ramię jeźdźca (jego widoczny fragment) sugeruje, że postać bierzgłowska mogła podobnie - trzymać księgę albo miecz widniejący , $\mathrm{W}$ tle” głowy ${ }^{19}$, tak jak rycerz na miniaturze $\mathrm{z}$ Wielkiej Kroniki Francuskiej z 1332-1350 r. (il. 6) lub w płaskorzeźbie rycerza

\footnotetext{
${ }^{16}$ A. Karłowska-Kamzowa, Ilustrowane Apokalipsy krzyżackie z XIV w., Toruń 1991, fot. 27 na s. 130.

${ }^{17}$ Dotychczasowe opisy niejednokrotnie różniły się od siebie: M. Kutzner, Propaganda władzy, s. 32: „z uniesionym nad głową mieczem i z tarczą bojową w lewej ręce”; później, w Herrschaftspropaganda, s. 269, zmienia określenie: „über der rechten Schulter”; G. Jurkowlaniec, T. Płóciennik, op. cit., s. 77, stwierdzają, że do dziś można rozpoznać tarczę i zarysy pochwy miecza, ale „trudno stwierdzić”, czy pozioma linia jest fragmentem miecza; K. Zawadzka, Portal, s. 12, widzi „miecz, który unosi nad wyprostowaną głową" i tarczę z krzyżem. B. Jakubowska we wspomnianym wyżej referacie dostrzega miecz na wysokości szyi, a tarczy nie możemy być pewni; A. Błażejewska, op. cit., s. 66: „,miecz [...] na wysokości dolnej partii głowy (lub szyi?)”.

${ }^{18}$ T. Mroczko, Geneza ikonografii Apokalipsy Wroctawskiej, Rocznik Historii Sztuki, 7, 1969, s. 47-106, il. 51a na s. 94: Liber Floridus, rkps z Wolfenbüttel, fol. 9vo .

${ }^{19}$ Miecz pojawia się tu w tym samym układzie (w sensie planów) co u postaci śpiącej i być może również oznacza umiejscowienie „za” głową.
} 
z Tudeli (XII w. ${ }^{20}$. Gdyby przyjąć takie „realistyczne” ujęcie połączone jeszcze $\mathrm{z}$ obecnością pochwy miecza, widocznej w wizerunku bierzgłowskim, to byłyby to argumenty przemawiające na niekorzyść wyobrażenia Chrystusa w portalu bierzgłowskim. Mimo tych kilku wątpliwości za wizerunkiem Chrystusa Apokaliptycznego przemawia też lokalizacja: w portalu wejściowym do zamku - pojmowanym przez Krzyżaków jako Niebiańskie Jeruzalem ${ }^{21}$. To wyobrażenie Chrystusa-Apokaliptycznego Jeźdźca byłoby swego rodzaju trawestacją tympanonów Sądu Ostatecznego w portalach kościołów, w tej formie ideowo bliższe zarówno Krzyżakom-,,rycerzom Chrystusa”, jak i dekoracji portali zamków tychże rycerzy ${ }^{22}$.

4. Przy próbach odczytu i interpretacji inskrypcji/fryzu literowego, które mają równie długą tradycję badawczą ${ }^{23}$, zastanawia kwestia dotychczasowej interpretacji ostatniej literowej płytki (prawy tuk portalu). Litera ta, a właściwie ślad (negatyw) po niej, jest podobna do odwróconego, majuskułowego M lub E (il. 7) ${ }^{24}$. Mimo że wiele można zarzucić odrysowi inskrypcji z 1848 r. autorstwa Neya, był on najbliższy prawdy, gdy chodzi o kształt znaku (litery) na ostatniej płytce (chociaż u niego jest odwrócona ${ }^{25}$. Przerys Steinbrechta ukazuje ten ostatni znak jako formę czworoliścia (można go odczytać też jako krzy$\dot{z} y k)^{26}$. Schmid niczego na niej nie rozpoznał ${ }^{27}$. Także inni badacze -

${ }^{20}$ Ostatnio ilustrację przywołuje K. Zawadzka, Portal, il. 10 na s. 30: repr. z J. Le Goff, Kultura średniowiecznej Europy, Warszawa 1970.

${ }^{21} \mathrm{O}$ nietypowej sakralnej formie architektonicznej zob. M. Kutzner, Propaganda, s. 32: używa nawet określenia - „kościelna”.

${ }^{22}$ Podobnie jak iluminacje krzyżackich komentarzy do apokalips są one indywidualnym pomysłem wykoncypowanym na potrzeby ideologii krzyżackiej w konkretnych, pruskich uwarunkowaniach: A. Karłowska-Kamzowa, op. cit., s. 81.

${ }^{23}$ Zestawienie propozycji odczytu u: L. Jagodziński, S. Skibiński, Analiza napisu nad brama zamku w Bierzglowie - propozycja komputerowej metody badań, [w:] Inskrypcje toruńskie, red. I. Sawicka, Toruń 1999, s. 59-73; G. Jurkowlaniec, T. Płóciennik, op. cit., 75-83.

${ }^{24}$ Bardziej przypomina „M”, lecz ze względu na stan zachowania nie można również wykluczyć, że była to litera E; W. Semkowicz, Paleografia łacińska, Kraków 2007, s. 285, 292, 299, 327, 332, 337, 353, 483.

${ }^{25}$ K. F. Ney, Zamek Birgłowski, Przyjaciel Ludu, 1848, nr 8, s. 60-63.

${ }^{26}$ K. Steinbrecht, Die Baukunst des Deutschen Ritterordens in Preussen. 2. Preussen zur Zeit der Landmeister. Beitraege zur Baukunst des Deutschen Ritterordens, 
Lech Jagodziński i Sławomir Skibiński - uznali ją jedynie za motyw zdobniczy ${ }^{28}$; Grażyna Jurkowlaniec i Tomasz Płóciennik również nie wzięli jej pod uwagę ${ }^{29}$. Spośród dotychczasowych interpretacji całej tej literowej dekoracji dwie wydają się najbardziej przekonujące: Mariana Kutznera oraz Grażyny Jurkowlaniec i Tomasza Płóciennika. W przypadku, gdy podtrzymamy tezę Kutznera o apotropaicznej funkcji przypadkowych liter (rodzaj magicznego zaklęcia) istnienie w tym miejscu litery, znaku czy pustej płytki ceramicznej nie ma znaczenia. Jednak w dość przekonującej propozycji odszyfrowania przedstawionej przez Jurkowlaniec i Płóciennika - *REGE IESV D(omi)NE [* D]E PACE D[omi]NI* [*..]M(?)[.]I REGNA [..]HCINT(?)[.]AS[..] ${ }^{* 30}$ (ale przy zmiennym kierunku czytania tekstu, zarówno od prawej do lewej, jak i odwrotnie $\left.{ }^{31}\right)$ - obecność tej ostatniej litery komplikuje sens przekazu, bo tworzyłaby wyraz REGEM (Acc. Sing. III dek1.).

Berlin 1888, Abb. 166; G. Jurkowlaniec i T. Płóciennikowi przypomina trójliść, op. cit., s. 82.

${ }^{27}$ B. Schmid, Die Inschriften des deutschen Ordenslandes Preußen bis zum Jahre 1466, Schriften der Königsberger Gelehrten Gesellschaft. Geisteswissenschaftliche Klasse, 11, H. 3, Haale 1935, s. 71-72.

${ }^{28}$ L. Jagodziński, S. Skibiński, op. cit., s. 68, oznaczyli ją nr 49 (na zamieszczonej ryc. 4) i nr 49 lub np. 47 (w tekście s. 66) w zależności od przyjętej liczby liter. Na ryc. 4, przydzielając jej konkretny nr 49 , jednocześnie informują o znajdującej się na rycinie numeracji poszczególnych liter. Warto również odnotować niedokładność odrysu i schematu zamieszczonego w publikacji i niekonsekwencję numeracji liter. Ponadto zaprezentowane przez L. Jagodzińskiego i S. Skibińskiego propozycje nowych, komputerowych metod badawczych w żadnym stopniu nie rozwiązują problemu. Wnioski, które miały się okazać rewolucyjne, niczego nowego nie wniosły, a pytania pozostały te same. Pierwsza z konkluzji: „Rysunek Neya jest niedokładny” (s. 65) wymagała jedynie porównania rysunku Neya ze stanem obecnym inskrypcji (!). Zatem trud badaczy był zbędny.

${ }^{29}$ Chociaż przywołują ją w stanie badań i przydzielają jej nr 50. Wspominając Jagodzińskiego i Skibińskiego podają, że ci autorzy nie widzą na niej niczego (!): G. Jurkowlaniec, T. Płóciennik, op. cit., s. 82.

${ }^{30}$ Tym bardziej, że tekst odpowiadałby domniemanemu wyobrażeniu Chrystusa w mandorli.

${ }^{31}$ G. Jurkowlaniec, T. Płóciennik, op. cit., s. 83, twierdzą, że inskrypcję układał analfabeta. Jest to mało prawdopodobne, żeby Krzyżacy zaakceptowali błędy w tak reprezentacyjnym portalu. 
Powyższe spostrzeżenia mają ,roboczy” charakter i są jedynie przyczynkiem do dalszej dyskusji. Jednak w ich kontekście warto zwrócić uwagę na znaczenie impulsu, jaki dla każdego rozpoznania naukowego ma obserwacja zabytku w terenie, co znakomicie wyrażają słowa Lecha Kalinowskiego w tekście pt. Nie myśl, lecz patrz. W odpowiedzi Antoniemu Ziembie: ,Jeżeli uwagi [...] mają wnosić nowe poznanie do wiedzy o temacie [obrazu], muszą być wynikiem uważnego nań patrzenia" $" 32$.

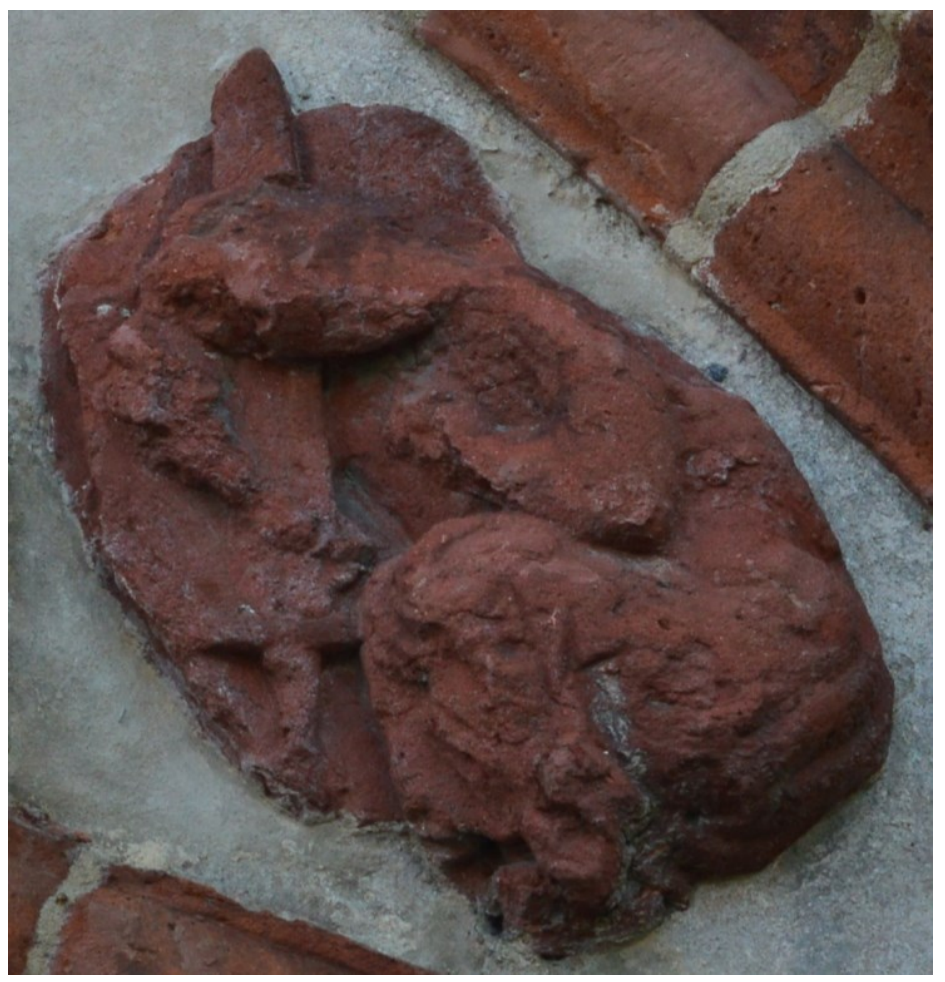

Il. 1. Postać śpiącego. Tympanon w portalu zamku bierzgłowskiego (fot. M. Dzienis)

\footnotetext{
${ }^{32}$ L. Kalinowski, Nie myśl, lecz patrz. W odpowiedzi Antoniemu Ziembie, Biuletyn Historii Sztuki, 60, nr 3/4, 1998, s. 463-464.
} 


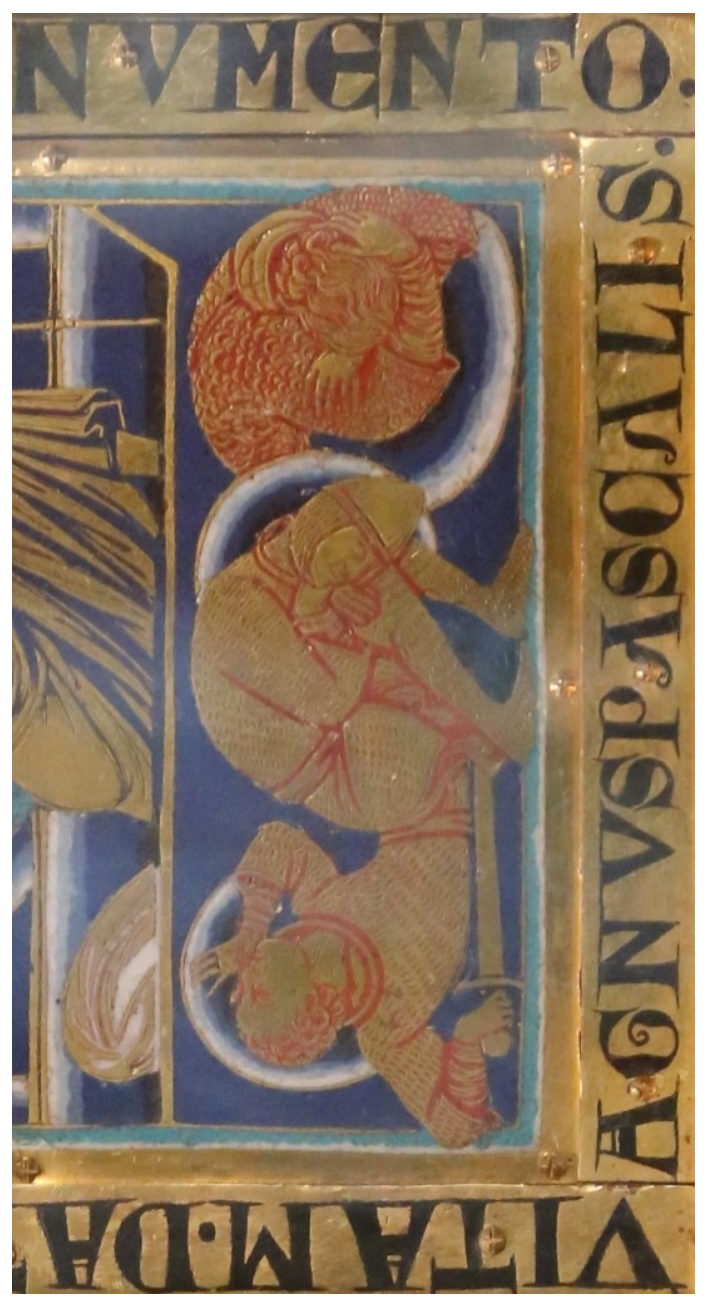

क્⿹

륭

密要它

N

훙

둥ㄹㅇㅝ

表

를

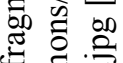

\&

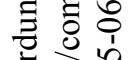

के

N

氶宩

क्ष

जी ते

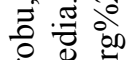

윰

$=$

ㄴ.

昆

i

인

की

त

$\exists 3$ 


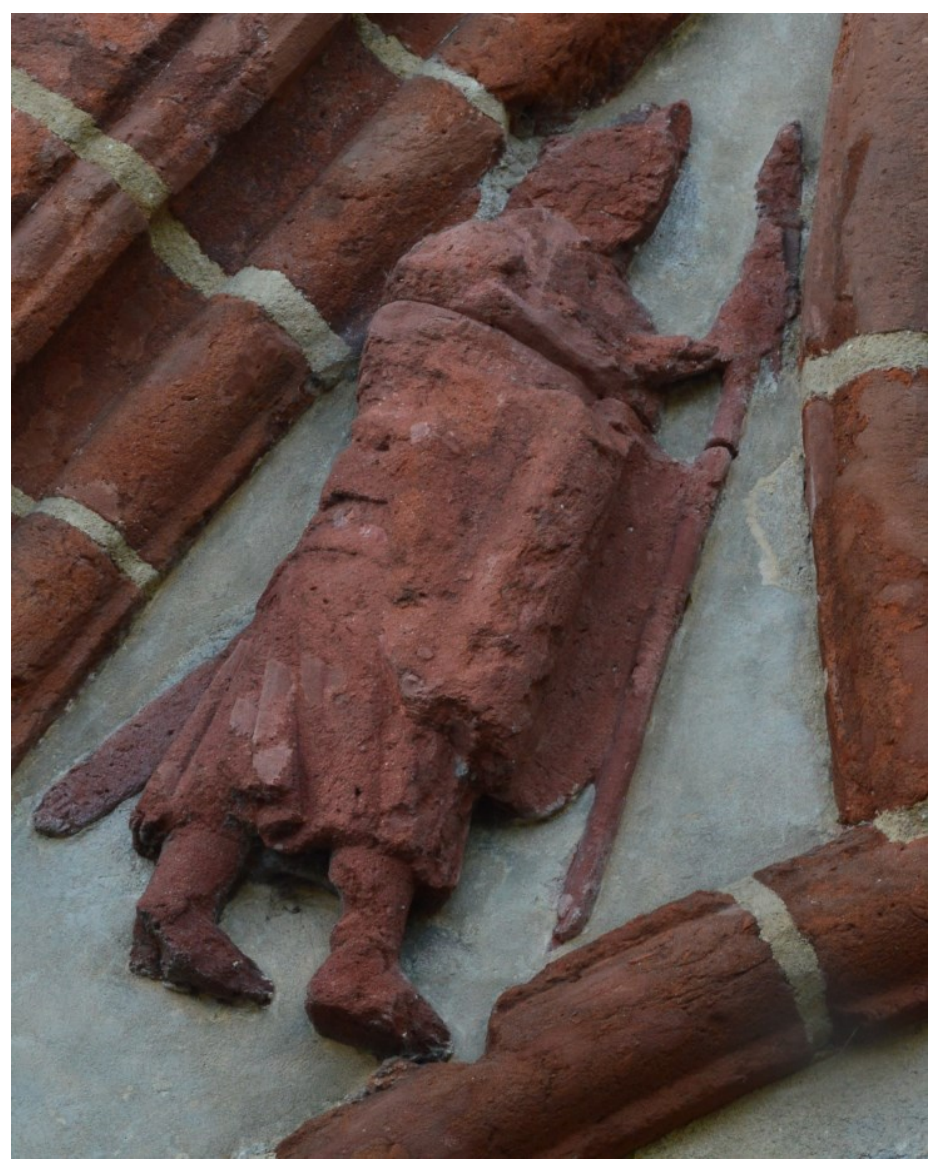

Il. 3. Postać krocząca. Tympanon w portalu zamku bierzgłowskiego (fot. M. Dzienis) 


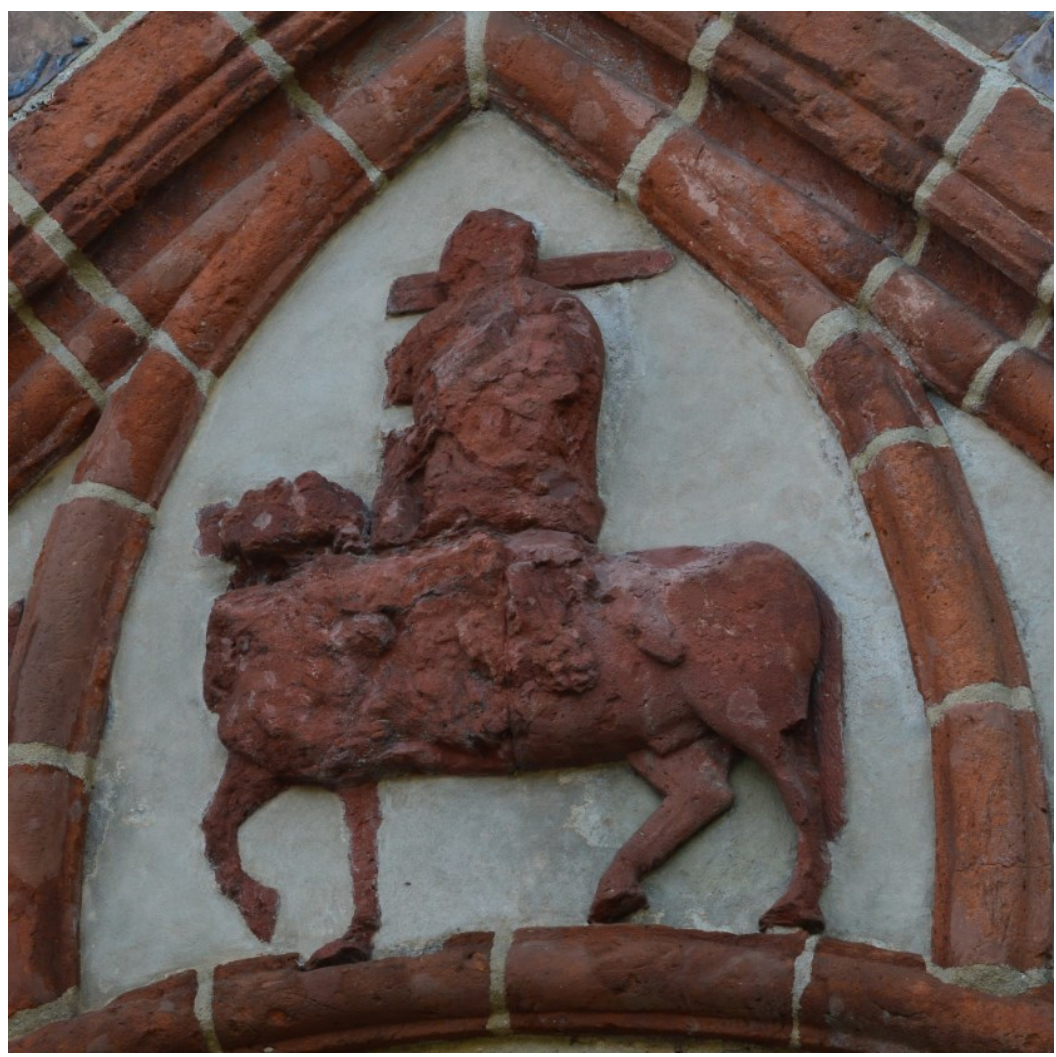

Il. 4. Postać jeźdźca. Tympanon w portalu zamku bierzgłowskiego (fot. M. Dzienis) 


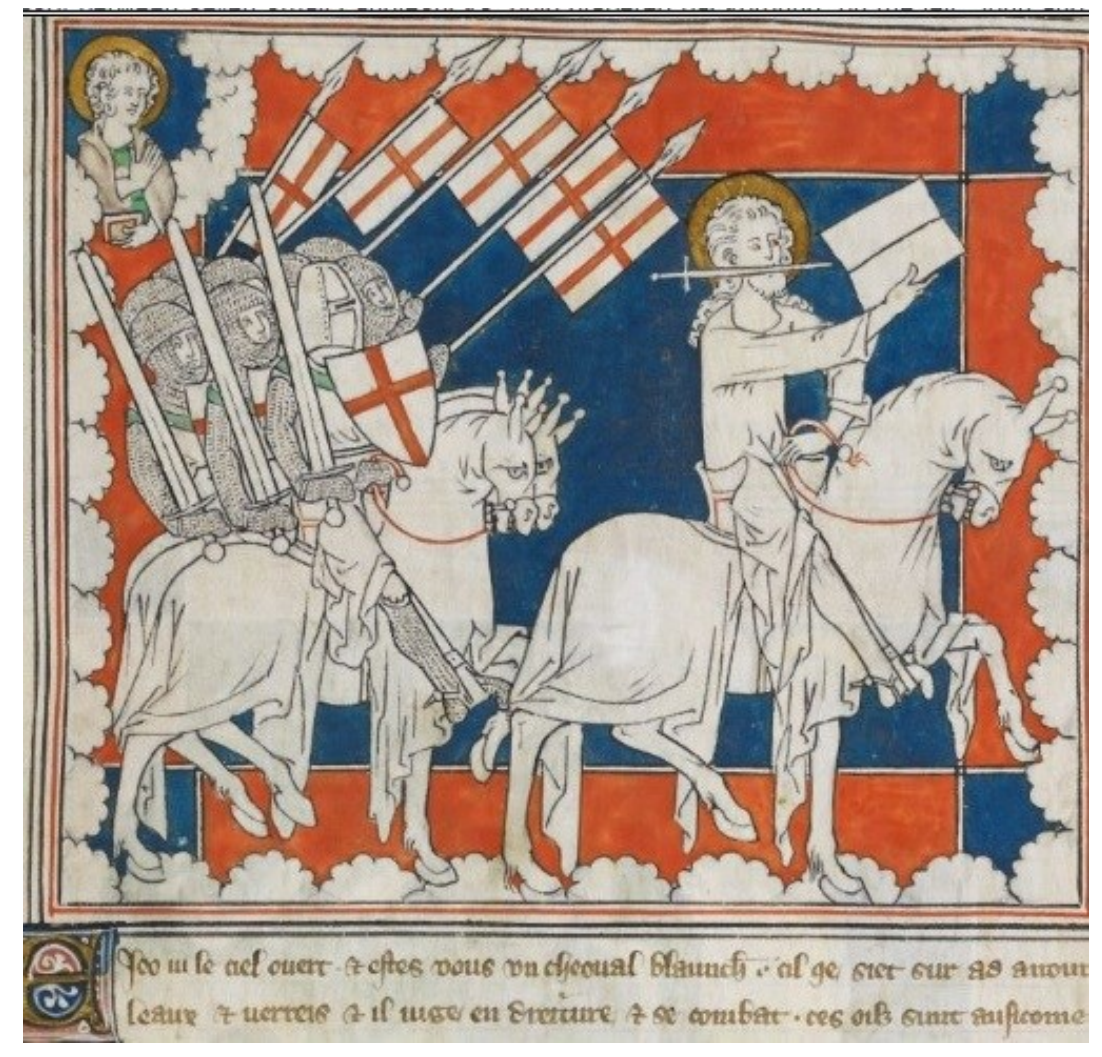

I1. 5. Chrystus prowadzący krzyżowców. Miniatura z „The Queen Mary Apocalypse", Londyn, British Library, Royal MS 19 B XV, fol. 37 r. (1. ćwierć XIV w.), wg http://www.bl.uk/manuscripts/Viewer.aspx? ref=royal_ms_19_b_xv_fs001r[dostęp: 09.08.2016 r.] 


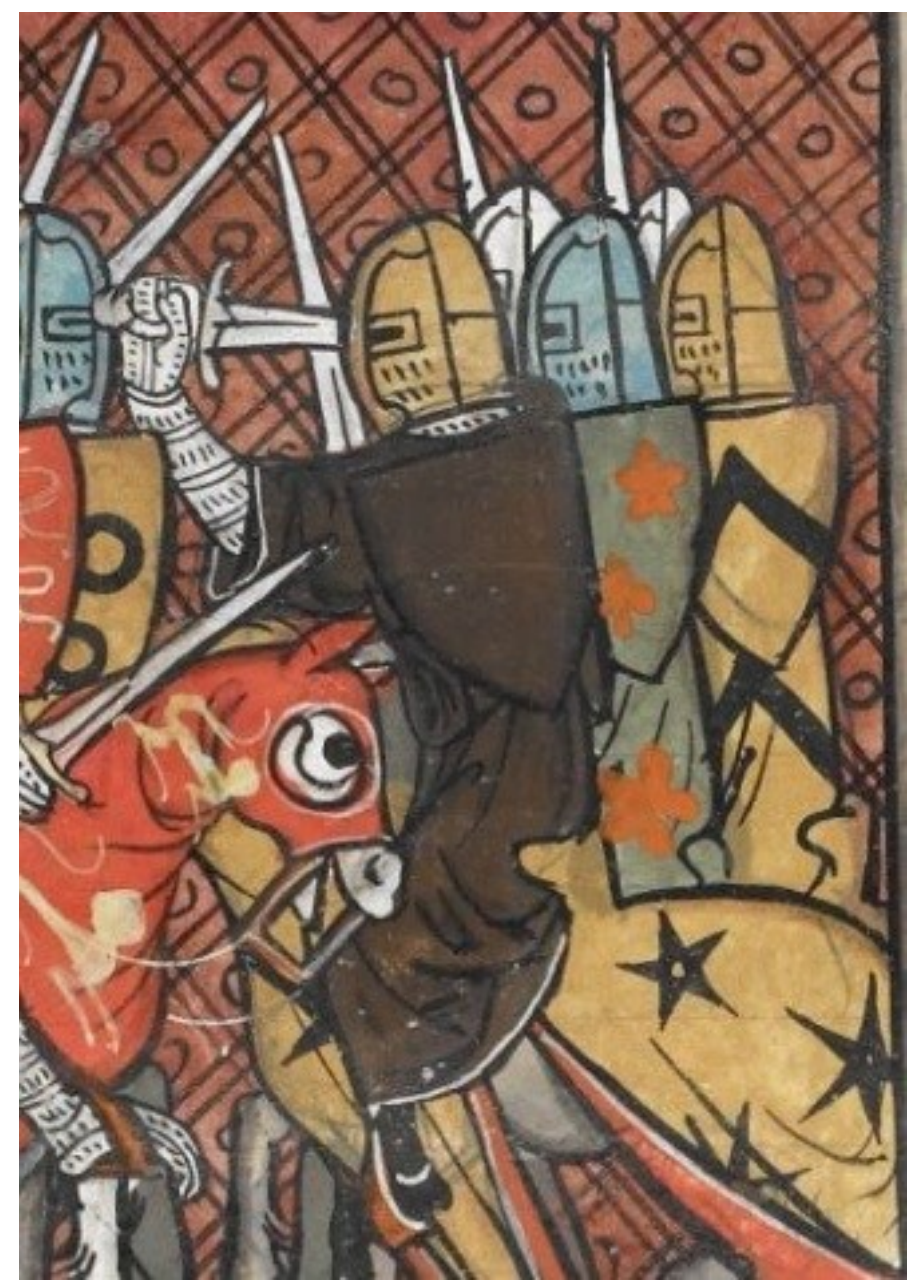

Il. 6. Rycerz z uniesionym mieczem. Fragment miniatury z Wielkiej Kroniki Francuskiej, Londyn, British Library, Royal MS 16 G VI, fol. 385 r. (1332-1350 r.), wg http://www. bl.uk/manuscripts/Viewer.aspx? ref=royal_ms_16_g_vi_fs001r[dostęp: 09.08.2016] 


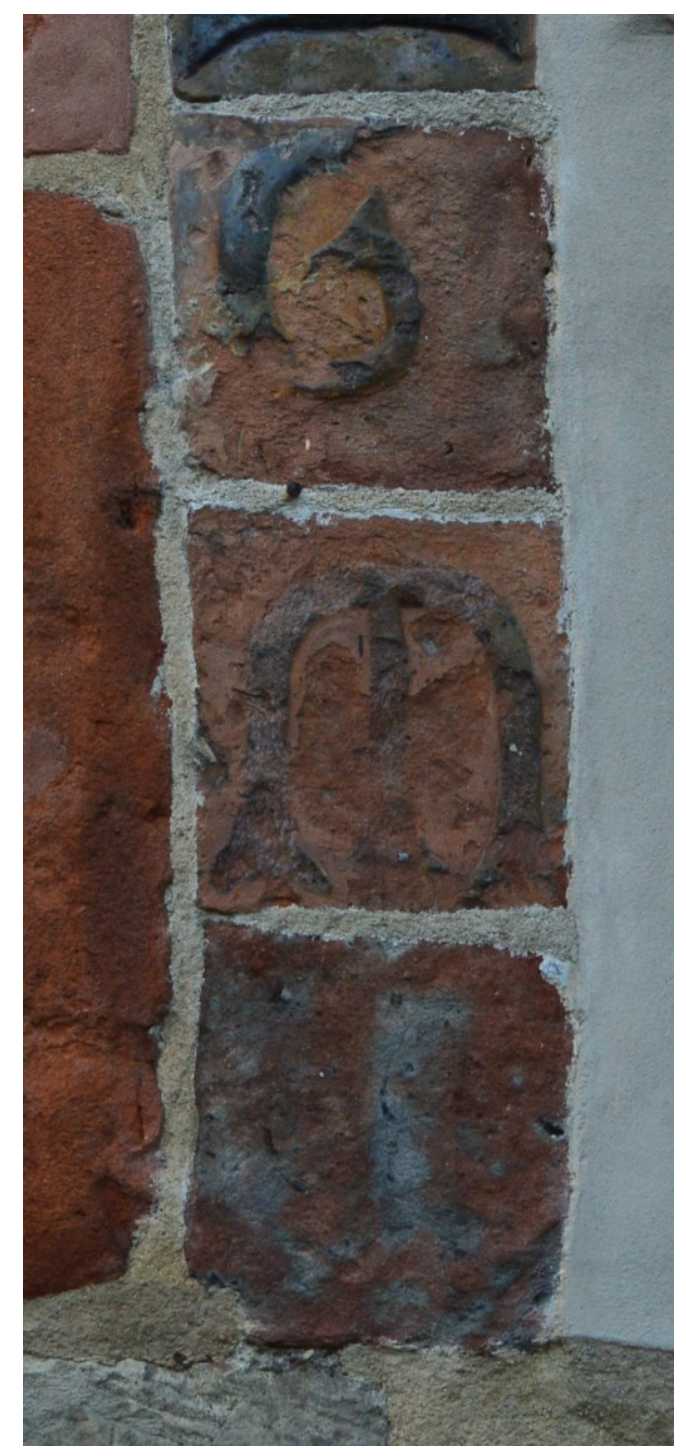

Il. 7. Fragment inskrypcji/fryzu literowego portalu zamku bierzgłowskiego - po prawej stronie (fot. M. Dzienis) 